\title{
Mesopotamian medical information in the divination series Šumma ālu
}

The proposed communication aims at presenting the preliminary results of my pilot research project "Mesopotamian medical notions in the divination series Šumma ālu". Thanks to the endowment of a Henri Frankfort Short-Term Fellowship, I have conducted this study at the Warburg Institute, School of Advanced Study, University of London (January-April 2019). The aim of this research was to conduct a first survey of all medical-related information comprised in the terrestrial omens of the series Šumma ālu. Medical sources provide useful information to the reconstruction of Babylonian scientific and intellectual history; however, if considered alone, they do not allow us to understand various aspects of medical rationale. For this reason, scholars have been interested also in sources outside the medical corpus. I decided to follow their footsteps by focusing on Šumma ālu, which has been labelled as an encyclopaedia for every aspect of ancient Mesopotamian everyday life. This line of enquiry has never been attempted before, as the medical corpus has been compared usually with magic, not divination. Moreover, the difficulties embodied by the processes of the textual edition of the divination series have slowed its accessibility. However, the edition of the first half of Šumma ālu has been completed recently, and two ongoing projects (Geneva, Vienna) are aimed at completing this task. The communication will present the general context of this pilot project, its preliminary results and its possible future developments. 